\title{
Mutational analysis of the interacting cell death regulators CED-9 and CED-4
}

\author{
Sabine Ottilie ${ }^{1,2}$, Yan Wang ${ }^{1}$, Sean Banks ${ }^{1}$, Julia Chang ${ }^{1}$, \\ Nicole J. Vigna ${ }^{1}$, Suzanne Weeks ${ }^{1}$, Robert C. Armstrong ${ }^{1}$, \\ Lawrence C. Fritz ${ }^{1}$ and Tilman Oltersdorf ${ }^{1}$ \\ 1 IDUN Pharmaceuticals, Inc. La Jolla, California, USA \\ 2 corresponding author: Dr Sabine Ottilie, IDUN Pharmaceuticals, Inc. $11085 \mathrm{~N}$. \\ Torrey Pines Road, Suite 300, La Jolla, California 92037, USA. \\ Tel: 619-623-1330; Fax: 619-625-2677; E-mail address: sottilie@idun.com
}

Received 28.4.97; revised 3.6.97; accepted 12.6.97

Edited by $G$ Melino

\begin{abstract}
The genes ced-3, ced- 4 and ced- 9 are central components in the cell death pathway of the nematode $C$. elegans. Ced-9, which functions to inhibit cell death, is homologous to the Bcl2 family of mammalian anti-apoptotic genes. The ced-3 gene encodes a protein homologous to the caspases, a family of cysteine proteases involved in the execution of programmed cell death. It has recently been demonstrated that CED-4, an inducer of apoptosis for which no mammalian equivalent has been reported, can interact with CED-9 and $\mathrm{Bcl}-\mathrm{X}_{\mathrm{L}}$. Here we confirm that CED-9 and CED-4 interact and using a series of deletion mutants, demonstrate that only short $\mathrm{N}$-terminal deletions are tolerated in each molecule without loss-ofinteraction. Two loss-of-function point mutations in different regions of CED-4 also lead to a significant loss of interaction suggesting further that the relevant interaction domains are not short linear sequences, but rather, are formed by more complex structural determinants in each molecule. Furthermore, we demonstrate that CED-4 not only interacts with Bcl$x_{L}$ but also with its homologue, $B c l-2$, and that the unstructured loop region present in $\mathrm{Bcl}-\mathrm{x}_{\mathrm{L}}$ and $\mathrm{Bcl}-2$ can regulate the CED-4 interaction. Lastly, we show that a $\mathrm{BH} 3$ peptide that can inhibit Bcl-2 family interactions also inhibits the interaction between Bcl- $x_{L}$ and CED-4.
\end{abstract}

Keywords: apoptosis; cell death; ced-9; ced-4; Bcl-2; Bcl- $\mathrm{x}_{\mathrm{L}}$; $\mathrm{BH}-3$ peptide

Abbreviations: ZVAD, benzyloxycarbonyl-Val-Ala-Asp-fluoromethylketone; aa, amino acid; GST, glutathionine-S-transferase; SDS-PAGE, sodium dodecyl sulfate polyacrylamide gelelectrophoresis; EDTA, ethylenediaminetetraaceticacid

\section{Introduction}

Programmed cell death (PCD) is an intrinsic biochemical pathway that plays an essential role in development and tissue homeostasis. Genetic studies in the nematode Caenorhabditis elegans have identified a number of genes that participate in the death pathway. The ced-3 gene product promotes cell death and is required to effect all developmentally regulated programmed cell deaths in C. elegans. Ced-3 encodes a nematode homologue of the growing family of cysteine proteases termed caspases (Yuan et al, 1993). The ced-9 gene product inhibits programmed cell death and encodes a nematode homologue of the mammalian $\mathrm{Bcl}-2$ family (Hengartner et al, 1992; Hengartner and Horvitz, 1994). The ced-4 gene, for which no mammalian homologue has been identified, exists as two alternatively spliced forms. The more abundant ced-4S promotes cell death, while ced-4L antagonizes cell death (Yuan and Horvitz, 1992; Shaham and Horvitz, 1996). Genetic studies in the worm have shown that ced-9 acts upstream to prevent the action of ced-3 and ced-4. In mammalian cells, biochemical analysis indicates that Bcl-2 acts upstream of at least some members of the caspase family of proteases (Armstrong et al, 1996; Chinnaiyan et al, 1996).

Recent studies using both cell-free systems and intact cells have demonstrated that the ced- 4 gene product can associate with the anti-apoptotic factor CED-9 and its mammalian homologue Bcl- $\mathrm{x}_{\mathrm{L}}$ (Chinnaiyan et al, 1997; Spector et al, 1997; Wu et al, 1997). In cells, this association can lead to the sequestration of CED-4 to the intracellular membrane compartments to which CED-9 is localized (Wu et al, 1997). In one report, CED-4 overexpression led to the activation of programmed cell death, an effect which was abrogated by co-expression of CED-9 or $\mathrm{BCl}-\mathrm{x}_{\mathrm{L}}$. Death induced by CED-4 overexpression was also inhibited by treatment of cells with the caspase inhibitor zVAD-fmk or co-expression of the viral encoded caspase inhibitors crmA or p35 (Chinnaiyan et al, 1997). These data suggested that the CED-4 function is upstream of caspase activation and that CED-9, via direct interaction, may inhibit the ability of CED-4 to act on a target effector. This model was further supported by the observation that CED-4 can directly associate with CED-3 and several mammalian caspase homologues (Chinnaiyan et al, 1997), suggesting that direct interaction of CED-4 with CED-3 may lead to protease activation and subsequent cell death.

In the present report we further characterize the association between CED-4 and CED-9. We show that CED-4S associates with CED-9, while CED-4L possesses greatly reduced binding activity. Deletion analysis of CED-4 and CED-9 suggests that their interaction requires nearly full length partners. We demonstrate that CED-4 binds to $\mathrm{Bcl}-2$ and $\mathrm{Bcl}-\mathrm{x}_{\mathrm{L}}$, the mammalian CED-9 homologues and that the CED-4/Bcl- $x_{L}$ interaction can be specifically blocked by a Bak BH3-derived peptide. Furthermore we demonstrate that a deletion of the unstructured 'loop'-region of Bcl-x $\mathrm{K}_{\mathrm{L}}$ (Muchmore et al, 1996) which enhances its antiapoptotic activity, also enhances its binding to CED-4. These data are discussed in the context of a molecular framework for apoptosis. 


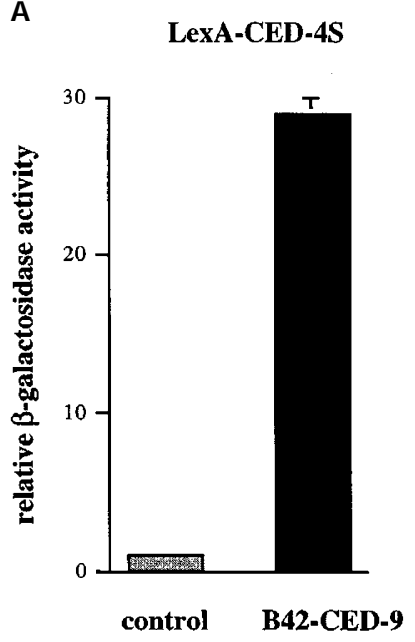

B

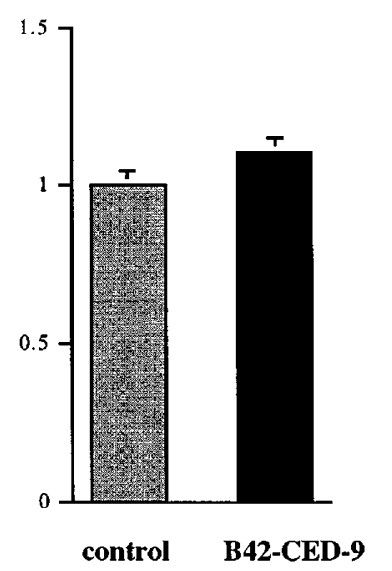

C

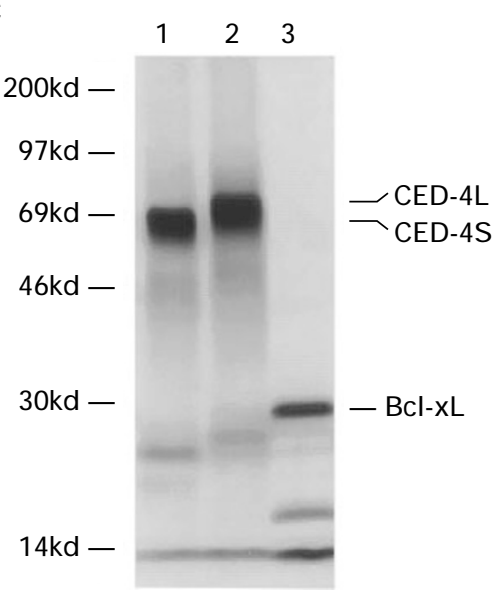

D

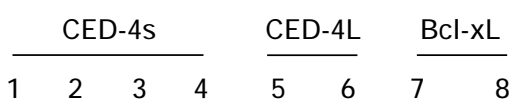

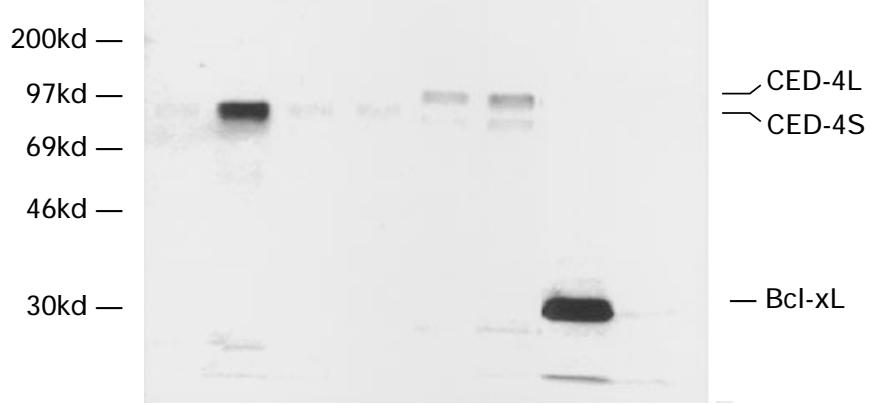

Figure 1 Interaction of CED-9 with CED-4. (A and B) Yeast 2-hybrid analysis. S. cerevisiae EGY191 cells were transformed with the pGilda expression plasmids producing the LexA DNA-binding domain fused to either CED-4S or CED-4L and the pJG4-5 plasmid expressing the B42-activation domain fused to CED-9 with the empty vector (control). The data are plotted as relative $\beta$-galactosidase activity and are based on $\beta$-galactosidase activity in cells expressing the respective bait and the control prey, which is defined as a value of 1.0. Results represent the means \pm the standard deviations of three different transformants assayed in duplicates. (C) Input of in vitro transcription/ translation. ${ }^{35}$ S-methionine labeled CED-4S (lane 1), CED-4L (lane 2) and Bcl-

\section{Results}

\section{CED-9 interacts directly with CED-4}

We used the yeast 2-hybrid system to determine whether CED-9 can directly interact with the two alternatively spliced forms of CED-4. We found that CED-9 (expressed in a soluble form without its $\mathrm{C}$-terminal membrane spanning domain) binds strongly to the death effector CED-4S (Figure 1A) but does not bind to CED-4L, the death-inhibitory isoform containing an additional 24 amino acid insertion (Shaham and Horvitz, 1996) (Figure 1B). Expression levels of these two versions of CED-4 proteins were comparable in Western Blot analysis (data not shown), excluding the possibility that differences in protein levels would account for the differences in interaction. The interaction of CED-4S and CED-9 can be detected by either using CED-9 as a LexA-DNA-bindingprotein fusion (bait) or a B42-transcriptional-activator-protein fusion (prey) and with CED-4S expressed as the complementary fusion protein. However the interaction between LexA-CED-4 and B42-CED-9 (Figure 1A) is approximately tenfold stronger than between LexA-CED-9 and B42-CED-4 (data not shown).

To confirm the interaction of CED-9 and CED-4, we performed co-precipitation experiments with in vitro translated ${ }^{35}$ S-CED-4 and purified glutathione-S-transferase-CED-9 (GST-CED-9) fusion protein. The data demonstrate a strong interaction between CED-4S and GST-CED9 (Figure $1 \mathrm{C}$ and $\mathrm{D}$ ), but only a weak interaction above background was detected between CED-4L and GST-CED9.

\section{Mapping of binding domains in CED-9}

CED-9 is an anti-apoptotic member of the Bcl-2 family and shares sequence similarity with $\mathrm{Bcl}-2$ and $\mathrm{Bcl}-\mathrm{x}_{\mathrm{L}}$. The similarities are clustered in several domains, termed $\mathrm{BH} 1-4$ domains (Yin et al, 1994; Chittenden et al, 1995; Zha et al, 1996). The recently described NMR and X-ray diffraction structure of $\mathrm{Bcl}-\mathrm{x}_{\mathrm{L}}$ suggest a hydrophobic groove formed by the $\mathrm{BH} 1, \mathrm{BH} 2$ and $\mathrm{BH} 3$ domains (Muchmore et al, 1996) into which the $\mathrm{BH} 3$ domain of a dimerization partner can insert (Sattler et al, 1997). The importance of these domains for dimer formation amongst mammalian family members is well documented (Yin et al, 1994; Sedlak et al, 1995; Diaz et al, 1997). We were similarly interested to analyze the structural requirements for CED-9 interaction with CED-4. We made a series of deletion constructs in CED-9 (all without membrane spanning domains) and assayed their ability to bind to CED-4 in the yeast 2-hybrid system (Figure 2). Our mapping analysis indicates that only small deletions of the $\mathrm{N}$-terminus are

$\mathrm{X}_{\mathrm{L}}$ (lane 3 ) were separated by SDS - PAGE and analyzed by autoradiography and by the Storm system (Molecular Dynamics). The amounts of various proteins loaded were one-fifth of the amount used in the co-precipitation experiments shown in D. (D) CED-4S binds to CED-9 in vitro. ${ }^{35} \mathrm{~S}$-methionine labeled CED-4S (lanes 1-4), CED-4L (lanes 5 and 6) and Bcl- $x_{L}$ (lanes 7 and 8) were incubated with either glutathione beads (lanes 1 and 5) or with various immobilized GST-tagged proteins (GST-CED9: lanes 2 and 6; GST-Bax: lanes 3 and 7; GST-Ras: lanes 4 and 8). The bound proteins were separated by SDS-PAGE and analyzed by autoradiography 
tolerated without a complete loss of interaction with CED-4. The $\Delta \mathrm{N}$-construct (aa $70-254$ ), containing the putative $\mathrm{BH} 1$, 2, 3 and 4 domains, still interacts with CED-4, albeit more weakly than the CED-9 wild-type construct. To rule out that the deletion mutants of CED- 9 do not interact with CED-4 due to low levels of protein expression we performed Western blot analyses and detected essentially equal amounts of protein (data not shown). These results suggest that the structure of CED-9 needs to be largely intact to preserve its ability to bind to CED-4.

\section{Mapping of binding domains in CED-4}

In order to analyze the structural requirements for CED-4 to bind to CED-9 we created a series of truncation mutants in CED-4 and assayed their interaction with CED- 9 in the yeast 2-hybrid system. A fragment lacking the first 90 amino acids interacts very strongly with CED- 9 while a fragment lacking the C-terminal 159 amino acids binds only weakly (Figure 3). Further truncation of the $\mathrm{N}$-terminus or $\mathrm{C}$-terminus abolishes interaction with CED-9 (Figure 3). A set of overlapping 120 amino acid fragments was also tested by yeast 2-hybrid analysis but none of them interacted with CED-9.

We correlated genetic analysis with direct protein-protein interaction studies, by analyzing loss-of-function mutations in CED-4 for their ability to bind to CED-9 in the yeast 2hybrid system. We introduced two loss-of-function CED-4 point mutations (Yuan and Horvitz, 1992 and H.R. Horvitz, pers. comm.) into the yeast CED-4 expression vector and assayed for binding to CED-9. The CED-4 (P23L) mutant loses about $80 \%$ of its activity when compared to wild-type CED4 (Figure 3). The mutant CED-4 (I258N) protein does not show any detectable interaction with CED-9 by either filter assay or in a quantitative liquid assay. To rule out that the lack of interaction of any of the CED4 point mutants merely reflects decreased protein expression levels we performed Western blot analysis with an anti-LexA-antibody and detected essentially equal amounts of proteins (data not shown).

\section{$\mathrm{Bcl}-2$ and $\mathrm{Bcl}-\mathrm{x}_{\mathrm{L}}$ interact directly with CED-4}

We next determined whether $\mathrm{Bcl}-2$ and $\mathrm{Bcl}-\mathrm{x}_{\mathrm{L}}$, the mammalian homologues of CED-9, interact with CED-4. Using the yeast 2-hybrid system and Bcl-2 family proteins expressed without transmembrane domains, we detected a reproducible but weak interaction between Bcl-2 and CED-4 but no detectable interaction between $\mathrm{Bcl}-\mathrm{x}_{\mathrm{L}}$ and $\mathrm{CED}-4$ (Figure 4A). Deletion mutants of Bcl-2 and $\mathrm{Bcl}-\mathrm{x}_{\mathrm{L}}$ which remove their unstructured 'loop' domains were recently reported to increase their anti-apoptotic activities (Muchmore et al, 1996; Chang et al, 1997). We tested these loopdeleted mutants for interaction with CED-4. The results indicate that deletion of the loop-domain in $\mathrm{Bcl}-2$ enhances slightly its interaction with CED-4 and a similar deletion in Bcl$X_{L}$ leads to a strong interaction with CED-4 (Figure 4A), comparable to the strength of interaction of CED- 4 with CED9 (see Figure 1A). To confirm the interaction of $\mathrm{Bcl}-2$ and $\mathrm{Bcl}-$ $x_{\mathrm{L}}$ with CED-4 we made in vitro ${ }^{35} \mathrm{~S}$-labeled $\mathrm{Bcl}-2$ and $\mathrm{BCl}-\mathrm{x}_{\mathrm{L}}$ full length proteins and incubated them with purified CED-46 His protein immobilized on protein A-sepharose. Immunoprecipitations of CED-4-6His co-precipitated ${ }^{35}$ S-labeled Bcl2 and $\mathrm{Bcl}-\mathrm{x}_{\mathrm{L}}$ but did not show binding to Bax (Figure 4B and $4 \mathrm{C})$. In this co-precipitation assay $\mathrm{Bcl}-\mathrm{x}_{\mathrm{L}}$ contained the unstructured loop but still showed robust binding to CED-4 in contrast to the yeast 2-hybrid results.

\section{Interaction with CED-4}

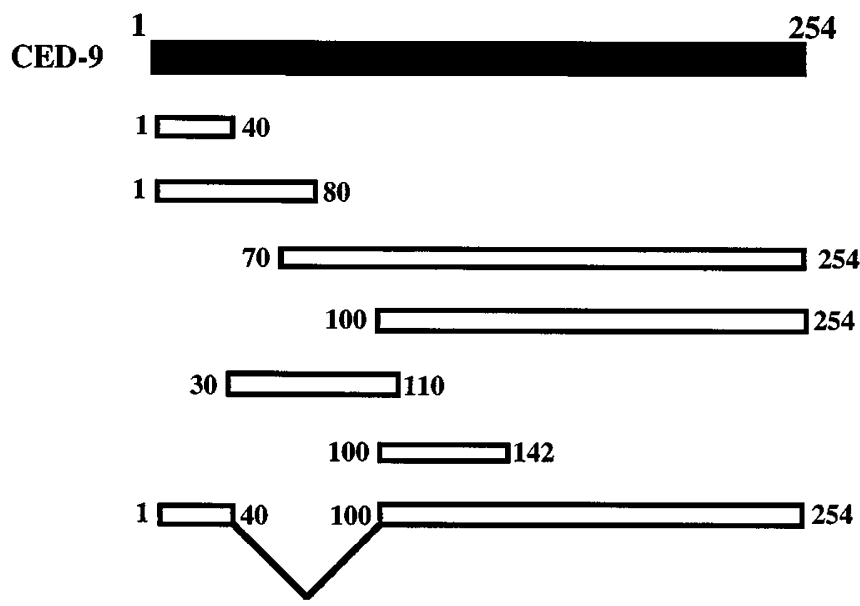

$\begin{array}{cc}\text { Filter assay } & \text { liquid assay }(\% \text { a } \\ +++ & 100 \\ - & 0 \\ - & \text { n.d. } \\ + & 12+/ \cdot 4 \\ - & 0 \\ - & 0 \\ - & 0 \\ - & 0\end{array}$

Figure 2 Mapping of CED-9 domains. S. cerevisiae EGY191 cells were transformed with the pGilda expression plasmid producing the LexA DNA-binding domain fused to CED-4S and the pJG4-5 plasmid expresing the B42-activation domain fused to a set of CED-9 deletion constructs, or with the empty vector (control). The strength of interaction is based on a visual filter assay and by a quantitative $\beta$-galactosidase assay. The interaction of wild-type CED-9 with CED-4 is defined as $100 \%$. Results represent the means \pm the standard deviations of six different transformants assayed in duplicates. +++ : strong blue color; + : light blue color; - : white 


\section{A BH3-peptide inhibits CED-4 binding to $\mathrm{Bcl}-\mathrm{x}_{\mathrm{L}}$}

It was recently shown that Bak binds into the $\mathrm{Bcl}-\mathrm{x}_{\mathrm{L}}$ binding pocket via its $\mathrm{BH} 3$ domain (Chittenden et al, 1995; Sattler et al, 1997) and that BH3-derived peptides can block dimerization of Bcl-2 family members (Diaz et al, 1997). We were interested to analyze whether CED-4 binding to $\mathrm{Bcl}-\mathrm{x}_{\mathrm{L}}$ can be blocked by a Bak BH3-peptide. We preincubated ${ }^{35} \mathrm{~S}$ labeled $\mathrm{Bcl}-\mathrm{x}_{\mathrm{L}}$ with a 16 amino acid peptide encompassing the Bak BH3-domain or a control Bak BH3 peptide containing several point mutations. The Bak peptide has previously been shown to block the formation of $\mathrm{Bax} / \mathrm{Bcl}-\mathrm{x}_{\mathrm{L}}$ dimers whereas the mutant peptide was inert (Diaz et al, 1997, and data not shown). Our results demonstrate that only the peptide with the wild-type Bak BH3-domain can inhibit CED-4 binding to $\mathrm{Bcl}-\mathrm{x}_{\mathrm{L}}$ (Figure 5). A peptide derived from the $\mathrm{BH} 4$ domain of $\mathrm{Bcl}-\mathrm{x}_{\mathrm{L}}$ does not inhibit interaction (data not shown) further demonstrating the specificity of the BH3-domain peptides.

\section{Discussion}

The genetic relationship in $C$. elegans between the cell death regulators ced-4 and ced-9 suggested the possibility of direct biochemical interaction between the two encoded proteins. In this study we have confirmed such a direct biochemical link by two independent methods: yeast 2-hybrid analysis and in vitro co-precipitation assays, consistent with recently published studies (Chinnaiyan et al, 1997; Spector et al, 1997; Wu et al, 1997).

We found a significant difference in binding of CED-9 to the two described splice variants of CED-4. CED-4S bound strongly to CED-9 whereas CED4-L interacted only weakly with CED-9, both in the yeast 2-hybrid system and in vitro co-precipitation experiments. These results confirm the data of Spector et al (1997) who also showed preferential binding of CED-9 to CED-4S. CED-4S and CED-4L have opposite function in the regulation of programmed cell death, CED-4S inducing cell death, while CED-4L displays

\section{Interaction with CED-9}

Filter assay liquid assay (\% activity)
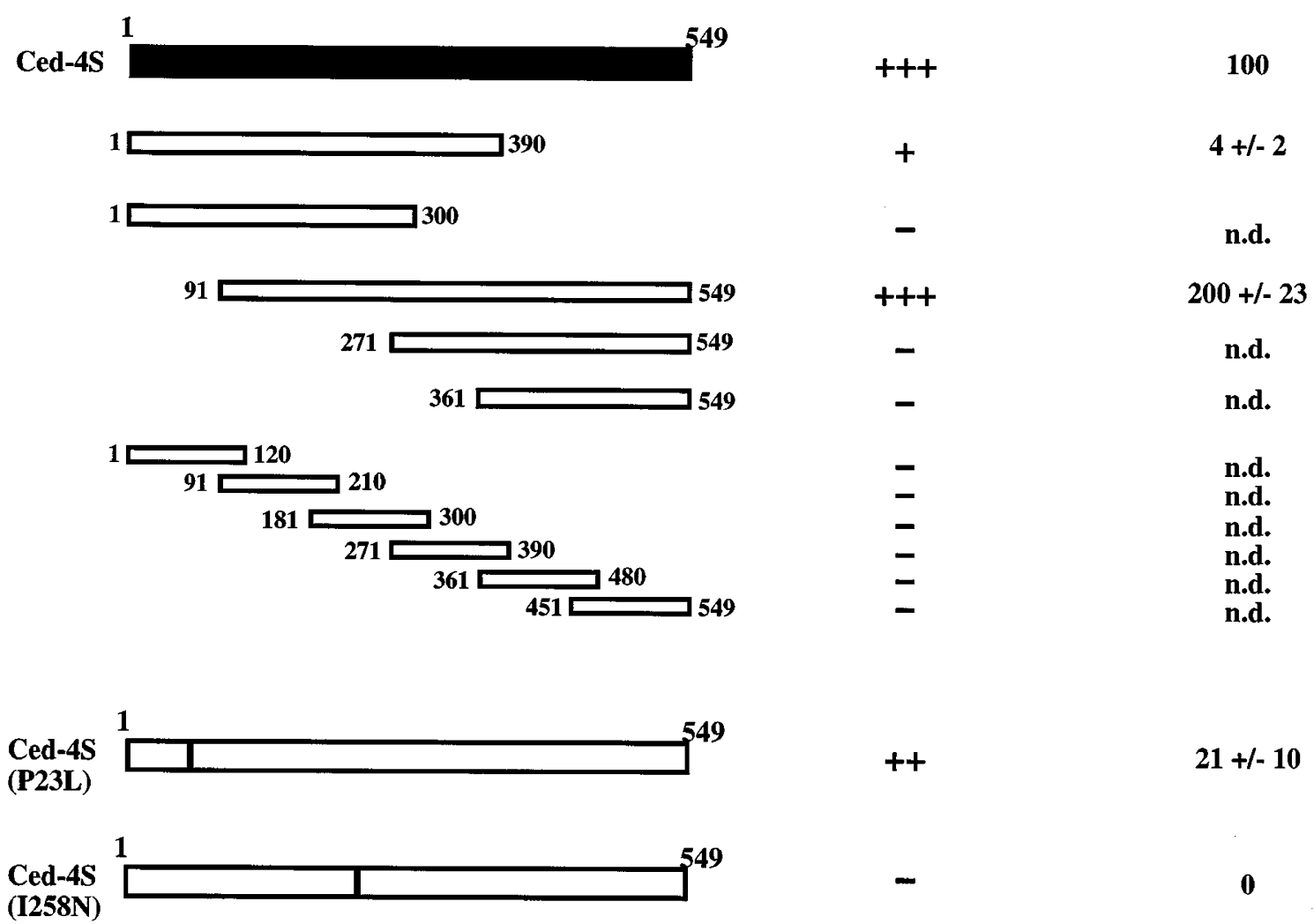

$++$

$21+/-10$

0

Figure 3 Mapping of CED-4S domains. S. cerevisiae EGY191 cells were transformed with the pGilda expression plasmids producing the LexA DNA-binding domain fused to a set of CED-4S constructs and the pJG4-5 plasmid expressing the B42-activation domain fused to CED-9, or with the empty vector (control). The strength of interaction is based on a visual filter assay and a quantitative $\beta$-galactosidase assay. The data are plotted as relative $\beta$-galactosidase activity and are based on $\beta$-galactosidase activity in cells expressing the respective bait and the control prey, which is defined as a value of 1.0 . Results represent the means \pm the standard deviations of at least six different transformants assayed in duplicates. +++: strong blue color; ++: medium blue color; +: light blue color; -: white 
a cell protective function (Shaham and Horvitz, 1996). Our results are in accord with a model that CED-9 antagonizes CED-4S pro-apoptotic activity by direct biochemical interaction, but does not oppose the anti-apoptotic molecule CED-4L.

Structural analysis of $\mathrm{Bcl}-\mathrm{x}_{\mathrm{L}}$ has revealed a hydrophobic binding groove formed by the $\mathrm{BH}-1, \mathrm{BH}-2$ and $\mathrm{BH}-3$ homology domains, while the $\mathrm{N}$-terminal $\mathrm{BH} 4$-domain was hypothesized to be important for stabilizing the $\mathrm{BCl}-\mathrm{x}_{\mathrm{L}}$ structure (Muchmore et al, 1996). Sequence alignments of CED-9 with $\mathrm{Bcl}-2$ family members demonstrate that CED-9 shows significant sequence conservation of these domains, suggesting a conserved three dimensional structure, possibly including a binding pocket for a dimerization partner. Our deletion mutant analysis of CED-9 reveals that only a small deletion of the $\mathrm{N}$-terminus, corresponding to a part of the CED-9 that is not present in either Bcl-2 or $\mathrm{BCl}-\mathrm{x}_{\mathrm{L}}$, can be tolerated without leading to a loss of

A

\section{LexA-CED-4S}

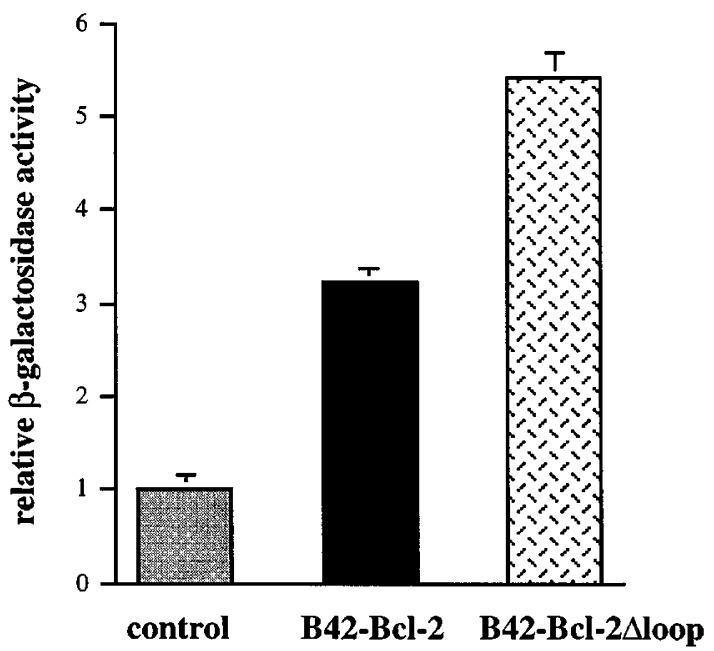

LexA-CED-4S

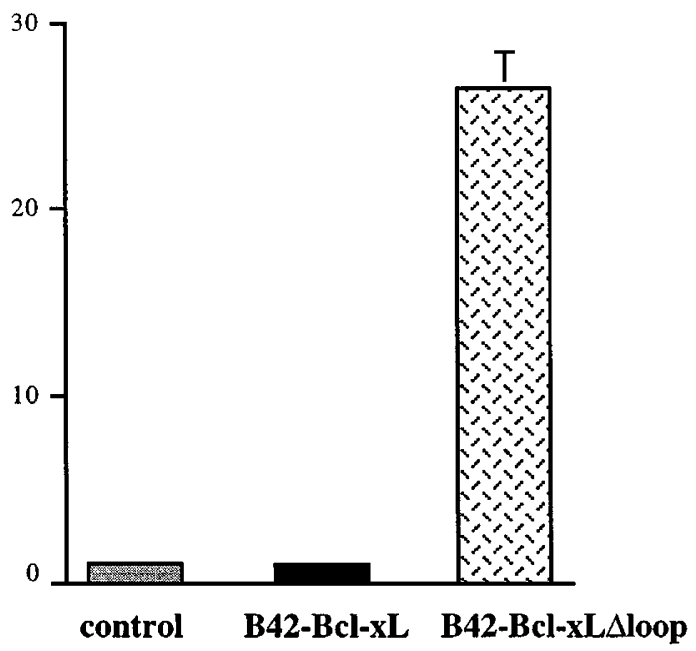

B

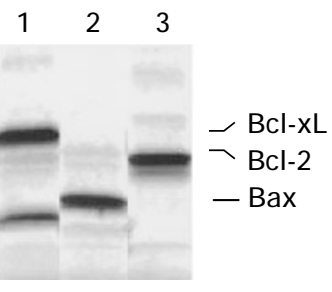

C

123

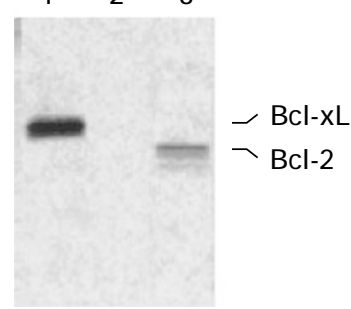

Figure 4 Interaction of Bcl-2 and Bcl-x $x_{L}$ with CED-4. (A) Yeast 2-hybrid analysis. S. cerevisiae EGY191 cells were transformed with the pGilda expression plasmid producing the LexA DNA-binding domain fused to CED-4S and the pJG4-5 plasmid expressing the B42-activation domain fused to Bcl-2, Bcl-2 $\Delta l$ loop, Bcl- $\mathrm{x}_{\mathrm{L}}, \mathrm{BCl}-$ $\mathrm{x}_{\mathrm{L}} \Delta$ loop or with the empty vector (control). The data are plotted as relative $\beta$-galactosidase activity and are based on $\beta$-galactosidase activity in cells expressing the respective bait and the control prey, which is defined as a value of 1.0. Results represent the means + the standard deviations of three different transformants assayed in duplicates. (B) Input of in vitro transcription/translation. ${ }^{35} \mathrm{~S}$-methionine labeled Bcl- $\mathrm{x}_{\mathrm{L}}$ (lane 1). Bax (lane 2) and Bcl-2 (lane 3) were seperated by SDS-

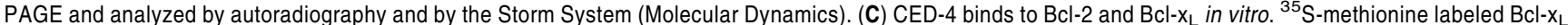
(lane 1), Bax (lane 2) and Bcl-2 (lane 3) were incubated with CED-4-6His fusion protein immobilized on protein A-sepharose beads. The bound proteins were separated by SDS-PAGE and analyzed by autoradiography 


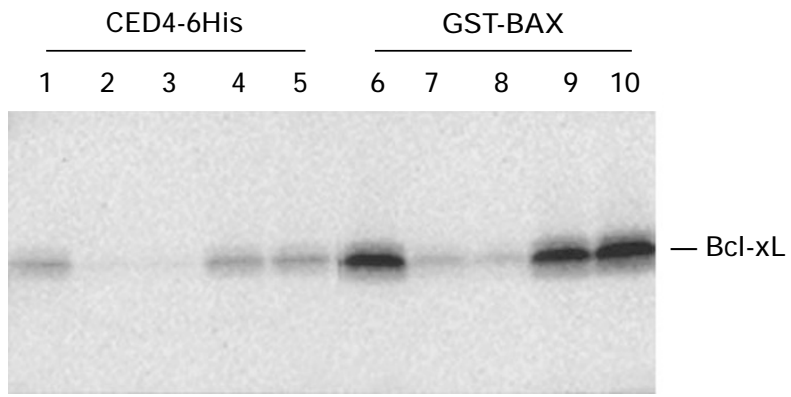

Figure 5 A Bak BH3-peptide inhibits CED-4 binding to $\mathrm{Bcl}-\mathrm{x}_{\mathrm{L}} .{ }^{35} \mathrm{~S}$ methionine labeled $\mathrm{Bcl}-\mathrm{x}_{\mathrm{L}}$ was preincubated with either no peptide (lanes 1 and 6) or with a Bak derived $\mathrm{BH} 3$-peptide in a final concentration of $10 \mu \mathrm{M}$ (lanes 2 and 7 ) or $40 \mu \mathrm{M}$ (lanes 3 and 8 ) or with a control Bak peptide (lanes 4 and $9,10 \mu \mathrm{M}$; lanes 5 and $10,40 \mu \mathrm{M}$ ) followed by an incubation with either immobilized CED-4-6His (lanes 1-5) or immobilized GST-Bax (lanes 6-10). The bound proteins were separated by SDS-PAGE and analyzed by autoradiography

interaction with CED-4. Further deletions of the N-terminus, including the putative $\mathrm{BH} 4$ domain lead to a complete loss of interaction. Our results suggest that CED-9 requires a correctly folded molecular structure consisting of intact $\mathrm{BH} 1,2,3$ and 4 domains.

Our analysis of CED-4 suggests that its interaction with CED-9 is also dependent on more than a short linear binding motif. First, deletion of the $\mathrm{N}$-terminal 90 amino acids was tolerated, larger $\mathrm{N}$-terminal or C-terminal truncations led to a loss of binding activity. Second, none of the overlapping 120 amino acid segments of CED-4 interacted with CED-9 in the yeast 2-hybrid assay. However, although full length CED-4 interacts with CED9, we cannot rule out that the $\mathrm{N}$-terminal fusion of the deletion mutants to LexA in the yeast 2-hybrid system had a negative influence on binding. And third, two loss-offunction mutations located in separate regions of the CED-4 sequence, P23L and I258N, have a major effect on the CED-9 interaction. The P23L mutation leads to an approximately $80 \%$ reduction in activity compared to wildtype CED-4, and the $1258 \mathrm{~N}$ mutation completely abolishes the interaction with CED-9. It was previously reported that the expression of CED-4S in 293 cells induces cell death, whereas the $1258 \mathrm{~N}$ mutant protein does not (Chinnaiyan et al, 1997). However, in that study the mutant protein was reported to be unstable, and thus it was not clear whether the mutation abolished the activity or whether lower protein concentrations accounted for the phenotype. Since in yeast the $1258 \mathrm{~N}$ mutant protein is as stable as the wild-type protein (data not shown), its failure to bind CED-9 is a true property of the mutant and not an artifact due to protein instability. Further work is required to determine whether the loss of function phenotype of these mutations is due to a loss of binding to CED-4 in C. elegans.

Our results demonstrate that the $C$. elegans CED-4 protein can interact not only with the $C$. elegans CED-9 protein but also with the mammalian homologues Bcl-2 and $\mathrm{Bcl}-\mathrm{x}_{\mathrm{L}}$. Bcl-2 shows weak but consistent and reproducible interaction with CED-4S in yeast 2-hybrid analysis as well as by in vitro coprecipitation. Bcl- $\mathrm{x}_{\mathrm{L}}$ did not show interaction in yeast 2-hybrid analysis, however, a deletion mutant of $\mathrm{Bcl}-\mathrm{x}_{\mathrm{L}}$ without the unstructured loop region (Muchmore et al, 1996) strongly interacted with CED-4. A similar deletion in $\mathrm{Bcl}-2$ also enhanced interaction with CED-4. It was recently shown that loop-deletion mutants of $\mathrm{Bcl}-\mathrm{x}_{\mathrm{L}}$ and $\mathrm{Bcl}-$ 2 show an enhanced ability to inhibit apoptosis and it was speculated that the loop domains suppress the antiapoptotic function of these molecules by being a target for post-translational modifications (Chang et al, 1997). The apparent discrepancy between the yeast 2-hybrid analysis and the in vitro precipitation assay for the Bcl- $\mathrm{x}_{\mathrm{L}}$ - CED-4 interaction could be due to several factors. The $\mathrm{N}$-terminal LexA-fusion used in the yeast 2-hybrid system may have an unpredictable effect on protein conformation and accessibility of binding domains. Alternatively, post-translational modifications of the loop-domain with known negative effects on the biological activity of $\mathrm{Bcl}-\mathrm{x}_{\mathrm{L}}$ (Chang et al, 1997) may negatively influence the binding to CED-4. Yeast cells are more efficient in the addition of some posttranslational modifications than reticulocyte lysates. Our data are consistent with a model in which $\mathrm{Bcl}-2$ and $\mathrm{Bcl}-\mathrm{x}_{\mathrm{L}}$ suppress the death promoting activity of a mammalian CED-4 homologue by direct biochemical interactions that are negatively regulated by the loop domain. We propose that the loop-deleted $\mathrm{Bcl}-2$ and $\mathrm{Bcl}-\mathrm{x}_{\mathrm{L}}$ molecules have enhanced anti-apoptotic activity by virtue of their enhanced ability to bind a pro-apoptotic CED-4 homologue.

It was recently shown that short peptide sequences derived from the $\mathrm{BH} 3$-domains of $\mathrm{Bcl}-2$ family members are sufficient to bind to the hydrophobic binding pocket of Bcl$\mathrm{X}_{\mathrm{L}}$ (Sattler et al, 1997) and that the dimerization of Bcl-2 family members can be blocked by peptides encoding $\mathrm{BH} 3-$ domains (Diaz et al, 1997). We demonstrated that CED-4 binding to $\mathrm{Bcl}-\mathrm{x}_{\mathrm{L}}$ can be specifically blocked with a Bakderived BH3-peptide. Our result is in accord with the observation that Bax expression inhibits the association of CED-4 with $\mathrm{Bcl}-\mathrm{x}_{\mathrm{L}}$ in transfected mammalian cells (Chinnaiyan et al, 1997), and further suggests that this Bax effect was due to a direct $\mathrm{BH} 3$ interaction with $\mathrm{Bcl}-\mathrm{x}_{\mathrm{L}}$. Our data thus support the idea that $\mathrm{BH} 3$-containing proteins induce cell death in mammalian cells by directly displacing a CED-4 homologue from Bcl-2 and Bcl- $x_{L}$.

Our $\mathrm{BH} 3$ peptide data suggest the possibility that $\mathrm{CED}-4$ contains a BH3-like domain that binds directly to the hydrophobic groove of $\mathrm{Bcl}-\mathrm{x}_{\mathrm{L}}$. If so, this domain lacks obvious sequence homology to the known $\mathrm{BH} 3$ domains. Alternatively, the binding of the $\mathrm{BH} 3$ peptide to the hydrophobic groove could induce a conformational change in the $\mathrm{BCl}-\mathrm{x}_{\mathrm{L}}$ molecule that inhibits CED-4 binding to a separate site. Additional studies will be necessary to distinguish between these possibilities and to further characterize the relevant binding sites.

\section{Materials and Methods}

\section{Plasmids}

CED-9 without a C-terminal putative transmembrane domain (residues 1-254), CED-4S (residues 1-549) and CED4L (residues 1-573) 
were PCR amplified and subcloned into the yeast 2-hybrid vectors pJG4-5 (Gyuris et al, 1993) and pGilda (C. Kaiser, Massachusetts Institute of Technology). Standard PCR procedures were used to generate the various deletion fragments of CED-4 and CED-9. The internal deletion construct of CED-9 was made by using a two-step PCR technique. The first step consisted of two PCR reactions generating two overlapping products which had the amino acids $40-$ 100 deleted. Using these two overlapping PCR products as a template, the second PCR reaction was performed with the two outside primers to generate the final internal deletion fragment. All constructs were confirmed by sequencing. pJG4-5-Bcl-2 and pJG4-5-Bcl- $x_{\mathrm{L}}$ constructs without $C$-terminal putative membrane spanning domains were described previously (Sato et al, 1994). Site-directed mutagenesis was performed to generate CED-4 (P23L) and CED-4 (I258N) by using the Quick-Change Kit (Stratagene) according to the manufacturer's

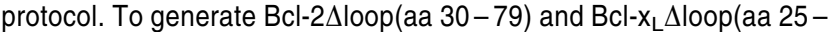
88 ) the Muta-Gene M13 Kit (BioRad) and the following oligonucleotides were used: 5'-CGC AGG CCC CGC GGC GGC CTC GTA GCC CCT CTG CGA-3' and 5'-CAG AAA GGA TAC AGC TGG GCC CTG AGG GAG GCA GGC-3'.

\section{Yeast 2-hybrid analysis}

A bait vector (LexA fusion protein), a prey vector (B42 fusion protein), and the $\beta$-galactosidase expression plasmid were transformed into the S. cerevisiae strain EGY191 (Gyuris et al, 1993). For filter assays and quantitative liquid assays at least three independent colonies were assayed in duplicates as described previously (Bertin et al, 1997).

\section{In vitro protein interaction assay}

For in vitro coprecipitation assays we employed the following two methods. ced-4S and ced-4L cDNAs in the Bluescript vector (Stratagene), and $\mathrm{Bcl}-\mathrm{x}_{\mathrm{L}} \mathrm{cDNA}$ in the pClneo vector (Promega) were used as templates for an in vitro transcription/translation reaction (TNT kit, Promega) in the presence of ${ }^{35} \mathrm{~S}$-methionine. Various GST-tagged gene products (CED-9, Bcl- $\mathrm{x}_{\mathrm{L}}, \mathrm{Bcl}-2, \mathrm{Bax}$ and Ras) were expressed from the pGEX-4T vector (Pharmacia) and purified by glutathione-Sepharose beads (Pharmacia). None of these proteins contains a putative transmembrane domain. Pre-cleared in vitro transcription/translation lysates were added to various GST fusion proteins immobilized on glutathione beads in the presence of $250 \mu \mathrm{l}$ immunoprecipitation buffer $(50 \mathrm{mM}$ Tris, $\mathrm{pH} 8.0,150 \mathrm{mM}$ $\mathrm{NaCl}, 2 \mathrm{mM}$ EDTA, $5 \mathrm{mM}$ DTT, $0.5 \%$ Nonidet P40). The reaction mixtures were incubated for $1.5 \mathrm{~h}$ at $4{ }^{\circ} \mathrm{C}$ and then washed four times with the immunoprecipitation buffer. Bound proteins were separated by SDS-PAGE and analyzed by autoradiography and by the Storm system (Molecular Dynamics). To analyze CED-4 binding to $\mathrm{Bcl}-2$ and $\mathrm{Bcl}-\mathrm{x}_{\mathrm{L}}$ the following methods were employed. $\mathrm{Bcl}-\mathrm{x}_{\mathrm{L}}$, $\mathrm{Bax}$ and $\mathrm{Bcl}-2 \mathrm{cDNAs}$ in the $\mathrm{pClneo}$ vector (Promega) were used as templates for in vitro transcription/translation reactions (TNT kit, Promega) in the presence of ${ }^{35} \mathrm{~S}$-methionine. The ced-4 cDNA was cloned into the Ncol site of pET15B (Novagen) to generate CED4$6 \mathrm{His}$ protein. The expressed protein was purified through Ni-NTA beads. The in vitro transcription/translation lysates were added to the CED-4-6His fusion protein immobilized on protein-A sepharose beads through an anti-6His antibody (Santa Cruz, \#SC804) in $250 \mu \mathrm{l}$ immunoprecipitation buffer. The reaction mixtures were incubated for $1.5 \mathrm{~h}$ at $4^{\circ} \mathrm{C}$ and washed four times with the immunoprecipitation buffer. Bound proteins were separated by SDS-PAGE and analyzed by autoradiography and by the Storm system (Molecular Dynamics).

\section{Peptide competition assay}

Peptide competition experiments were performed using the same procedure as described above except that the $10 \mu \mathrm{M}$ and $40 \mu \mathrm{M}$ of the following peptides: Bak BH3 peptide: GQVGRLAIIGDDINR and control Bak peptide: GQDGRQEAIIRRLINR were preincubated with either immobilized CED-4-6His or GST-BAX at $4{ }^{\circ} \mathrm{C}$ for 30 min before ${ }^{35} \mathrm{~S}$ labeled $\mathrm{Bcl}-\mathrm{X}_{\mathrm{L}}$ was added. Bound proteins were separated by SDSPAGE and analyzed by autoradiography and by the Storm system (Molecular Dynamics).

\section{Acknowledgements}

We would like to thank E. Davison, H.R. Horvitz, A. Madi and S. Shaham for sharing with us unpublished information concerning the CED-4 (P23L) mutation.

\section{References}

Armstrong RC, Aja T, Xiang J, Gaur S, Krebs JF, Hoang K, Bai X, Korsmeyer SJ, Karanewsky DS, Fritz LC and Tomaselli K (1996) Fas-induced activation of the cell death-related protease CPP32 is inhibited by Bcl-2 and ICE family protease inhibitors. J. Biol. Chem. 271: 16850-16855

Bertin J, Armstrong RC, Ottilie S, Martin DA, Wang Y, Banks S, Wang GH, Senkevich TG, Alnemri ES, Moss B, Lenardo MJ, Tomaselli KJ and Cohen JI (1997) Death effector domain-containing herpesvirus and poxvirus proteins inhibit both Fasand TNFR1-induced apoptosis. Proc. Natl. Acad. Sci. 94: 1172-1176

Chang BS, Minn AJ, Muchmore SW, Fesik SW and Thompson CB (1977) Identification of a novel regulatory domain in Bcl-xl and Bcl-2. EMBO J 16: 968-977

Chinnaiyan AM, Orth K, O'Rourke K, Duan H, Poirer GG and Dixit VM (1996) Molecular ordering of the cell death pathway. $\mathrm{Bcl}-2$ and $\mathrm{Bcl}-\mathrm{x}_{\mathrm{L}}$ function upstream of the CED-3-like apoptotic proteases. J. Biol. Chem. 271: 4573-4576

Chinnaiyan AM, O'Rourke K, Lane BR and Dixit VM (1997) Interaction of CED-4 with CED-3 and CED-9: A molecular framework for cell death. Science 275: $1122-$ 1126

Chittenden T, Flemington C, Houghton AB, Ebb RG, Gallo GJ, Elangovan B Chinnadurai $G$ and Lutz RJ (1995) A conserved domain in Bax, distinct from BH1 and $\mathrm{BH} 2$ mediates cell death and protein binding functions. EMBO J. 14:55895596

Diaz JL, Oltersdorf T, Horne W, McConnell M, Wilson G, Weeks S, Garcia T and Fritz LC (1997) A common binding site mediates heterodimerization and homodimerization of Bcl-2 family members. J. Biol. Chem. 272: 11350

Gyuris J, Golemis E, Chertkov H and Brent R (1993) Cdi, a human G1 and S phase protein phosphatase that associates with Cdk2. Cell 75: 791-803

Hengartner MO, Ellis RE and Horvitz HR (1992) Caenorhabditis elegans gene ced- 9 protects cells from programmed cell death. Nature 356: 494-499

Hengartner MO and Horvitz HR (1994) C. elegans cell survival gene ced-9 encodes a functional homolog of the mammalian protooncogene bcl-2 Cell 76: 665-676

Muchmore SW, SattlerM, Liang H, Meadows RP, Harlan JE, Yoon HS, Nettesheim D, Chang BS, Thompson CB, Wong SL, Ng SC and Fesik SW (1996)X-ray and NMR structure of human $\mathrm{Bcl}-\mathrm{xL}$, an inhibitor of programmed cell death. Nature 381 : $335-341$

Sato T, Hanada M, Bodrug S, Irie S, Iwama N, Boise LH, Thompson CB, Golemis E, Fong L, Wang HG and Reed JC (1994) Interactions among members of the Bcl-2 protein family analyzed with a yeast two-hybrid system. Proc. Natl. Acad. Sci. 91: $9238-9242$

Sattler M, Liang H, Nettesheim D, Meadows RP, Harlan JE, Eberstadt M, Yoon HS, Shuker SB, Chang BS, Minn AJ, Thompson CB and Fesik SW (1997) Structure of $\mathrm{Bcl}-\mathrm{x}_{\mathrm{L}}$-Bak peptide complex: recognition between regulators of apoptosis. Science 275: 983-986

Sedlak TW, Oltvai ZN, Yang E, Wang K, Boise LH, Thompson CB and Korsmeyer SJ (1995) Multiple Bcl-2 family members demonstrate selective dimerization with Bax. Proc. Natl. Acad. Sci. USA 92: 7834-7838

Shaham S and Horvitz HR (1996) An alternatively spliced C. elegans ced-4 RNA encodes a novel cell death inhibitor. Cell 86: 201-208 
Spector MS, Desnoyers S, Hoeppner DJ and Hengartner MO (1997) Interaction between the $C$. elegans cell-death regulators CED-9 and CED-4. Nature 385: 653-656

Wu D, Wallen HD and Nunez G (1977) Interaction and regulation of subcellular localization of CED-4 by CED-9. Science 275: $1126-1129$

Yin XM, Oltvai ZN and Korsmeyer SJ (1994) BH1 and BH2 domains of Bcl-2 are required for inhibition of apoptosis and heterodimerization with Bax. Nature 369: $321-323$

Yuan J and Horvitz HR (1992) The Caenorhabditis elegans cell death gene ced-4 encodes a novel protein and is expressed during the period of extensive programmed cell death. Development 116: $309-320$
Yuan J, Shaham S, Ledoux S, Ellis HM and Horvitz HR (1993) The C. elegans cell death gene ced-3 encodes a protein similar to mammalian interleukin- $1 \beta$ converting enzyme. Cell 75: 641-652

Zha H, Aime-Sempe C, Sato T and Reed JC (1996) Proapoptotic protein Bax heterodimerizes with $\mathrm{Bcl}-2$ and homodimerizes with $\mathrm{Bax}$ via a novel domain (BH3) distinct from BH1 and BH2. J. Biol. Chem. 271: 7440-7444 